\title{
Asymptomatic Bacteriuria in Pregnant Women at Kosti Teaching Hospital, Kosti-White Nile State (Sudan)
}

\author{
Omer Mohammed Ali Ibrahim', Mohammed E.H. Azoz ${ }^{2 *}$, \\ Abdalbagi Abdallah Mohie Eldeen ${ }^{3}$, Mohammed Ibrahim Alsadig ${ }^{3}$, \\ Mahdi B.A. Alagab ${ }^{4}$ and Abdelmageed Elmugabil ${ }^{4}$
}

\author{
${ }^{1}$ Department of Microbiology, ${ }^{2}$ Department of Surgery, ${ }^{4}$ Department of Obstetrics and \\ gynecology, Faculty of Medicine and Health Sciences, \\ University of El-imam El-mahdi Kosti city, Sudan \\ ${ }^{3}$ Department of Microbiology, Faculty of Medical Laboratory Sciences, \\ University of El-imam El-mhadi, Sudan \\ *Corresponding author
}

\begin{tabular}{|l|}
\hline K e y w o r d s \\
$\begin{array}{l}\text { Staphylococcus } \\
\text { saprophyticus, } \\
\text { Streptococcus agalactiae, } \\
\text { Klebsiella pneumoniae }\end{array}$ \\
\hline Article Info \\
\hline $\begin{array}{l}\text { Accepted: } \\
\text { 06 May } 2018 \\
\text { Available Online: } \\
\text { 10 June } 2018\end{array}$ \\
\hline
\end{tabular}

\section{A B S T R A C T}

Asymptomatic bacteriuria is a condition in which urine reveals significant growth; with no symptoms and signs of urinary tract infection, it is common during pregnancy and lead to serious complications. The objectives of this study were to determine the frequency of asymptomatic bacteriuria among pregnant women in Kosti teaching hospital, department of Obstetrics (White Nile State- Kosti-Sudan) and to identify the causative organisms and their antibiotics susceptibility pattern. This study was a prospective descriptive cross sectional study conducted in the department of Obstetrics and Gynecology at Kosti teaching hospital, from January to March 2017. A total of 192 pregnant women with no symptoms and signs of urinary tract infection were enrolled in the study. Midstream urine sample for culture was collected from each participant. All urine samples were inoculated on cystine lactose electrolyte deficient (CLED) and blood agar media, and incubated aerobically for $24 \mathrm{~h}$ at $37^{\circ} \mathrm{C}$. The colonies then identified by Gram staining technique and conventional biochemical tests. Antibiotics susceptibility testing of the isolated organisms was done by using Kirby Bauer disc diffusion method. Out of the 192 pregnant women enrolled in the study, the prevalence of asymptomatic bacteriuria was $25 / 192(13 \%)$. The study showed that asymptomatic bacteriuria was significantly associated with the age of the pregnant women ( $\mathrm{P}$ value 0.009$)$, the prevalence increase with decrease in age and it was $25 \%$ in the age group (12-20 years), $11.93 \%$ in the age group (21-30) and only $2.56 \%$ among the age group above 30 years. The differences of asymptomatic bacteriuria according to the trimesters was not significant $(\mathrm{P}$ value $=0.264)$. Escherichia coli was the most frequent causal organism 8/25(32\%) followed by Proteus species 7/25(28\%), Klebsiella pneumoniae 4(16\%), Staphylococcus saprophyticus 3/25(12\%), Pseudomonas aeruginosa $2 / 25(8 \%)$ and Streptococcus agalactiae $1 / 25(4 \%)$. Isolates revealed high susceptibility to amikacin (84\%), followed by ciprofloxacin (76\%), and gentamycin $(56 \%)$.However, all isolates were resistant to cotrimoxazole. High prevalence of asymptomatic bacteriuria was noted among pregnant women in Kosti teaching hospital and more common in younger pregnant. Escherichia coli was the most frequent isolate. Most of the isolated bacteria were sensitive to Amikacin and Ciprofloxacin. 


\section{Introduction}

Bacteriuria is the presence of bacteria in urine. (Kunin, 1994). It is generally accepted that $10^{5}$ or more colony forming units of bacteria per milliliter of urine is significant bacetriuria whether the patient is symptomatic or asymptomatic (Najar et al., 2009). Asymptomatic bacteriuria is a condition in which urine culture reveals the presence of more than $10^{5}$ bacteria per milliliter but without the patient showing symptoms of urinary tract infection (Scott et al., 1990). The diagnosis relies upon microbiologic findings (Garingalo-Molina, 2000; Ali et al., 2011). Asymptomatic bacteriuria is common in pregnancy and may lead to serious complications. It leads to acute cystitis in (40\%) and pyelonephritis in (25-30\%) (Scott et al., 1990). Pyelonephritis can lead to prenatal and maternal complications, including preterm delivery, low birth weight, fetal mortality, hypertension, anemia and renal insufficiency (Gilstrap and Ramin, 2001; Smail and Vazquez, 2007; Cunningham et al., 2010; Foxman, 2010). The reduction in immunity of pregnant women appears to encourage the growth of both commensally and non-commensally microorganisms (Stamm and Hooton, 1993). Many researchers have reports on the prevalence of asymptomatic bateriuria among pregnant women (Bloomberg et al., 2005). It has been reported in $20 \%$ of the pregnant women and it is the most cause of admission in obstetrical wards (Ali et al., 2011; Obirikorang et al., 2012). Asymptomatic bacteriuria has been reported among $13.0 \%$ pregnant women at Khartoum North Hospital, Sudan (Hamdan et al., 2011).

\section{Patients and Methods}

This study carried out at department of Obstetrics and Gynecology-Kosti teaching hospital, Kosti - White Nile State -Sudan, during the period from January to March 2017. It is a prospective cross sectional descriptive study. One hundred and ninety tow pregnant women with no symptoms of urinary tract infections, with different age and different gestational age come to department of Obse and Gyne - Kosti teaching hospital, were enrolled in this study. Non pregnant or pregnant women with symptomatic urinary tract infection were excluded. From each participant midstream urine sample for culture was collected in sterile containers. Personal and clinical data were obtained by a questionnaire.

\section{Isolation and identification}

Using calibrated loop method all urine samples were inoculated on cystine lactose electrolyte deficient (CLED) and blood agar media, and incubated aerobically for $24 \mathrm{~h}$ at $37^{\circ} \mathrm{C}$. After studding the colonial morphology, the colonies then identified by Gram staining technique and conventional biochemical tests.

\section{Antimicrobial susceptibility testing}

Susceptibility of isolated organisms to gentamicin (10ug), amikacin (30ug), ciprofloxacin (5ug) and co- trimoxazole (25ug) were tested by Kirby Bauer disc diffusion method. Suspensions of the isolates were adjusted to turbidity of 0.5 McFarland standards. Then the bacterial suspensions were spread on Mueller-Hinton agar and antibiotics discs placed on agar. All plates were incubated at $37^{\circ} \mathrm{C}$ for 24 hours. Zones of inhibition of the isolates were measured and reported as susceptible or resistant.

\section{Results and Discussion}

This study was conducted on the period from January to March 2017 at Kosti teaching hospital, department of Obse and Gyne. The prevalence of asymptomatic bacteriuria in 
pregnant women at Kosti teaching hospital was $25 / 192(13 \%)$. The study revealed that $25 \%$ of pregnant women in the first trimester attending at Kosti hospital were with asymptomatic bacteriuria, and lesser percentages were noted in women in the second and third trimesters $11.7 \%$ and $11.6 \%$, respectively (Table 1). However, the different of asymptomatic bacteriuria according to the trimesters was not significant $(\mathrm{P}$ value $=$ 0.264). Escherichia coli was the most frequent isolated organisms $8 / 25(32 \%)$ followed by Proteus species 7/25(28\%), Klebsiella pneumoniae 4/25(16\%) for each, Staphylococcus saprophyticus 3/25(12\%), Pseudomonas aeruginosa 2/25(8\%) and Streptococcus agalactiae 1/25(4\%) (Table 2). The study showed that asymptomatic bacteriuria was significantly associated with the younger pregnant women $(\leq 30$ years) and decreased among older pregnant women ( $\mathrm{P}$ value 0.009 ). Hence asymptomatic bacteriuria was noted in $25 \%$ of pregnant women in the age group (12-20 years), $11.93 \%$ in the age group (21-30) and only $2.56 \%$ among age group above 30 years as shown in Table 3. The isolated bacteria showed high susceptibility to amikacin (84\%), followed by ciprofloxacin $(76 \%)$, and gentamycin $(56 \%)$. However; all isolates were resistant to cotrimoxazole as shown in Table 4.

The complication of asymptomatic bacteriuria in pregnant women results in increase of morbidity of the mothers and has effects on the fetus which may result in fetal growth retardation, hypertension and anemia. In this study the prevalence of asymptomatic bacteriuria in pregnant women at Kosti teaching hospital was $13 \%$ this is lower than the earlier $78.7 \%$ reported in Nigeria (Amadi et al., 2007) and $16.1 \%$ reported in Ethiopia (Nisha et al., 2015). It is higher than that reported in Ghana, Ethiopia and Saudia Arabia $1.7 \%$ - 8.6\% (Turpin et al., 2007; GabreSelassie, 1998; Debebe, 2005; Al Sibiani, 2011).

The most prevalence organism observed in this study was Escherichia coli 8/25(32\%), This finding agrees with earlier reports showed that Escherichia coli was the most predominant etiological agent in asymptotic bacteruria in pregnant women, with variable percentages from $25.2 \%$ to $53 \%$ (Nisha et al., 2015; Turpin et al., 2007; Debebe, 2005; Al Sibiani, 2011; Blomberg et al., 2005). This could be due to the fact that Escherichia coli is a predominant microorganism in intestinal tract that can contaminate the skin area near to urethral opening and poor hygienic practices by pregnant women enhance entry of the organism to urinary tract causing infections.

In this study it was noted that the differences of asymptomatic bacteriuria according to the trimesters was not significant $(\mathrm{P}$ value $=$ 0.264), this is in agreement with findings reported by other researchers (Olusanya et al., 1993; Selassie, 1998; Sheikh et al., 2000; Ayoyi et al., 2017) they reported that gestational age of the participants did not have any statistical significant influence on asymptomatic bacteriuria.

\begin{tabular}{|c|c|c|c|c|}
\hline Asymptomatic bacteruria & $1^{\text {st }}$ trimester & $2^{\text {nd }}$ trimester & $3^{\text {rd }}$ trimester & Total \\
\hline Positive & $5(25 \%)$ & $7(11.7 \%)$ & $13(11.6 \%)$ & $25(13 \%)$ \\
\hline Negative & $15(75 \%)$ & $53(88.3 \%)$ & $99(88.4 \%)$ & $167(87 \%)$ \\
\hline Total specimens & $20(100 \%)$ & $60(100 \%)$ & $112(100 \%)$ & $192(100 \%)$ \\
\hline$P$ value $=0.264$ & & & & \\
\hline
\end{tabular}


Table.2 Shows the distribution of isolated bacterial species from urine in relation to pregnancy duration (trimesters)

\begin{tabular}{|l|c|c|c|c|}
\hline Organisms & $\mathbf{1}^{\text {st }}$ trimester & $\mathbf{2}^{\text {nd }}$ trimester & $\mathbf{3}^{\text {rd }}$ trimester & Total \\
\hline Proteus species & 1 & 2 & 4 & $7(28 \%)$ \\
\hline Escherichia coli & 1 & 1 & 6 & $8(32 \%)$ \\
\hline Klebsiella pnewmonice & 2 & 2 & 0 & $4(16 \%)$ \\
\hline Pseudomonas aeruginosa & 0 & 0 & 2 & $2(8 \%)$ \\
\hline Staphylococcus saprophyticus & 1 & 1 & 1 & $3(12 \%)$ \\
\hline Streptococcus agalactiae & 0 & 1 & 0 & $1(4 \%)$ \\
\hline Total isolates & $5(100 \%)$ & $7(100 \%)$ & $13(100 \%)$ & $25(100 \%)$ \\
\hline
\end{tabular}

Table.3 Shows the frequency of significant bacterial growth of urine culture in relation to the age of the pregnant women

\begin{tabular}{|l|c|c|c|c|}
\hline Age group & $\mathbf{1 2 - 2 0}$ years & $\mathbf{2 1 - 3 0}$ years & 31-40 years & Total \\
\hline Significant Growth & $11(25 \%)$ & $13(11.93 \%)$ & $1(2.56 \%)$ & $25(13 \%)$ \\
\hline Insignificant or no growth & $33(75 \%)$ & $96(88.07 \%)$ & $38(97.44 \%)$ & $167(87.5 \%)$ \\
\hline Total & $44(100 \%)$ & $109(100 \%)$ & $39(100 \%)$ & $192(100 \%)$ \\
\hline P value $=\mathbf{0 . 0 0 9}$ & & &
\end{tabular}

Table.4 Shows the antibiotics susceptibility test for isolated bacteria

\begin{tabular}{|l|c|c|c|}
\hline Antibiotic & Susceptible & Resistant & Total tested isolates \\
\hline Ciprofloxcin & $19(76 \%)$ & $6(24 \%)$ & $25(100 \%)$ \\
\hline Amikacin & $21(84 \%)$ & $4(16 \%)$ & $25(100 \%)$ \\
\hline Gentamycin & $14(56 \%)$ & $11(44 \%)$ & $25(100 \%)$ \\
\hline Cotrimoxazole & 0 & $25(100 \%)$ & $25(100 \%)$ \\
\hline
\end{tabular}

However, Awonuga found increasing prevalence with gestational age (Awonuga et al., 2010), and Nnatu found decreasing prevalence with duration of pregnancy (Nnatu et al., 1989). The study showed that asymptomatic bacteriuria was significantly associated with the younger pregnant $(\leq 30$ years) and decreases among older pregnant $(\mathrm{P}$ value 0.009), this result is in agreement with some researchers (Savage et al., 1967; Kandil et al., 1982) who observed a much higher prevalence of asymptomatic bacteriuria in younger pregnant women. However, the finding differs from those reported by Kass, Gaymans group, and Woodman (Kass, 1962; Gaymans et al., 1976; Woodman, 2001) who have found a progressive rise in prevalence of bacteriuria with increasing age. It was also reported that age of the pregnant women did not have any significant influence on asymptomatic bacteriuria (Ayoyi et al., 2017).

The highest susceptibility of isolated bacteria to antibiotics was noted with amikacin (84\%), followed by ciprofloxacin (76\%), and gentamycin $(56 \%)$. However, all isolates were resistant to cotrimoxazole. The antibiotic resistant pattern of isolated bacteria in the study could be due to antibiotic abuse and self-medication being common in Sudan.

Asymptomatic bacteriuria had high prevalence among pregnant women at Kosti teaching hospital especially that of age less than thirty years. The most isolated bacteria in asymptomatic bacteriuria was Escherichia 
coli. Amikacin and ciprofloxacin were the effective antibiotics against most isolated bacteria. Routine urine culture should be carried out on all pregnant women in order to detect asymptomatic bacteriuria and to allow its early treatment in order to avoid its complications.

\section{References}

Al Sibiani S. A. Asymptomatic Bacteriuria in Pregnant Women in Jeddah, Western Region of Saudi Arabia: Call for Assessment. JKAU: Med. Sci. 2011; 17(1): 29-42. DOI: 10.4197/Med. $17-$ 1.4

Ali R, Afzal U, Kausar S. Asymptomatic bacteriuria among pregnant women. Annals of Punjab Medical College. 2011; 5(2).

Amadi ES, Enemuo OB, Uneke CJ, Nwosu OK, Onyeagba RA, Ugbogu OC. Asymptomatic bacteriuria among pregnant women in Abakaliki, Ebonyi State, Nigeria J Med Sci 2007; 7(4): 698-700.

Awonuga DO et al., Predictors of asymptomatic bacteriuria among obstetric population in Ibadan. Niger $J$ Med J Natl Assoc. 2010; 19(2): 188193.

Ayoyi A, O., Kikuvi G, Bii C2, Samuel Kariuki S. Prevalence, aetiology and antibiotic sensitivity profile of asymptomatic bacteriuria isolates from pregnant women in selected antenatal clinic from Nairobi, Kenya. The Pan African Medical Journal. 2017; 26: 41. doi:10.11604/pamj.2017.26.41.10975

Blomberg B, Olsen BE, Hinderaker SG, Langeland N, Gasheka P. Antimicrobial resistance in urinary bacterial isolates from pregnancy women in rural Tanzania: Implications for public health. Scand J Infect Dis. 2005; 37: 262-268.
Bloomberg B., Olsen B.E., Hinderaker S.G., Langeland N., Gasheka P., Jureen R., Kvale G., Midtvedt T. Antimicrobial resistance in urinary bacterial isolates from pregnancy women in rural Tanzania. Implications for public health. Scandinavian Journal of Infectious Diseases, vol. 37, No.4, 262268, 2005.

Cunningham FG, Leveno KJ, Bloom SL, Hauth JC, Rouse DJ, Spong CY. Renal and urinary tract disorders. Williams Obstetrics. 23rd Edition, McGraw Hill Medical. 2010; 4: 1034 - 1036.

Debebe S., Asymptomatic bacteruria in pregnant women in Harar, South Ethiopia. A Thesis presented to the school of Graduate Studies, Addis Ababa University In partial fulfillment of the requirement for M.Sc. Degree in Medical Microbiology July, 2005; 31-3

Foxman B. The epidemiology of urinary tract infection. Nat Rev Urol 2010; 7(12): 653-60.

Gabre-Selassie S. Asymptomatic bacteriuria in pregnancy; epidemiological clinical and microbiological approach. Ethiop Med J 1998; 36: 185-192.

Garingalo-Molina FD. Asymptomatic bacteriuria among pregnant women; Overview of diagnostic approaches. Phil J Microbial Infect Dis. 2000; 29: 177-86.

Gaymans, R., Haverkorn, M. J., Valkenburg, H. A. and Galings, W. R. D. A prospective study of urinary tract infection in a Dutch general practice. Lancet. 1976; 2: 674-77.

Gilstrap LC 3rd, and Ramin SM. Urinary tract infections during pregnancy. Obstet Gynecol Clin North Am 2001; 28: 58191.

Hamdan HZ, Ziad AH, Ali SK, Adam I. Epidemiology of urinary tract infections and antibiotics sensitivity among pregnant women at Khartoum North 
Hospital. Ann Clin Microbiol Antimicrob. 2011; 10(2).

Kandil, O. F., Saleh, A. A., Hindaway, D. S. and Mohammed, A. M. Asymptomatic bacteriuria in Saudi females. Proceedings of seventh Saudi Arabia, 1982; 318-323.

Kass, E. H. Pyelonephritis and bacteriuria. Ann. Intern. Med. 1962; 56: 46-53

Kunin C.M. Urinary Tract Infections in Females. Clinical Infectious Diseases, 1994; 18, (1): 1-10.

Najar M.S., Saldanha C.L., Banday K.A. Approach to urinary tract infections. Indian Journal of Nephrology, 2009; 19, 129-139

Nisha A.K, Etana A.E, and TessoH. Prevalence of asymptomatic bacteriuria during pregnancy in Adama city, Ethiopia. International Journal of Microbiology and Immunology Research, 2015; 3(5), 058-063

Nnatu S, Essien EE, Akinkugbe AA. Asymptomatic bacteriuria in pregnant Nigerian patients. Clin Exp Obstet Gynecol. 1989; 16(4): 126-129.

Obirikorang C, Quaye L, et al., Asymptomatic bacteriuria among pregnant women attending antenatal clinic at the University Hospital, Kumasi, Ghana. Journal of Medical and Biomedical Sciences. 2012; 1(1): 38-44.

Olusanya, O., Ogunledun, A. and Fakoya, T. A. Asymptomatic significant bacteriuria among pregnant and non-pregnant women in Sagamu, Nigeria. W. Afri. Med. Jan-March, 1993; 12(1): 27-33.
Savage, W. E., Hajj, S. N. and Kass E. H. Demographic and prognostic characteristics of bacteriuria in pregnancy. Medicine. 1967; 46, 385405.

Scott E.M., McGarrigle H.H., Lacheline G.C. The increase in Plasma and Saliva Cortisol Levels in Pregnancy is not due to the increase in corticosteroid-binding globulin levels. The Journal of Clinical Endocrinology and Metabolism, Vol. 71, No. 3, 639-644, 1990. DOI: 10.1210/jcem-71-3-639.

Selassie, S. G. Asymptomatic bacteriuira in pregnancy: Epidemiological, Clinical and Microbiological Approach. Ethiop. Med. J. 1998; 36: 185-92.

Sheikh, M.A., Khan, M.S., Khatoon, A. and Arain, G.M. Incidence of urinary tract infection during pregnancy. Eastern Mediterranean Health Journal. 2000; 6(213) PP 265-271.

Smail F, and Vazquez JC. Antibiotics for asymptomatic bacteriuria in pregnancy. Cochrane Database of systematic Reviews 2007; 2: 224

Stamm W.E., and Hooton T.M. Management of urinary tract infections in Adults. The New England Journal of Medicine, Vol. 329, 1328-1334, 1993.

Turpin CA, Minkah B, Danso KA, Frimpong EH. Asymptomatic bacteriuria in pregnant women attending antenatal clinic at Komfo Anokye Teaching Hospital, Kumasi, Ghana. Ghana Med J 2007; 41(1): 26-29.

Woodman, P. J. Urinary tract infections in pregnancy. eMedicine J. 2001; Jul 2; 2

\section{How to cite this article:}

Omer Mohammed Ali Ibrahim, Mohammed E.H. Azoz, Abdalbagi Abdallah Mohie Eldeen, Mohammed Ibrahim Alsadig, Mahdi B.A. Alagab and Abdelmageed Elmugabil. 2018. Asymptomatic Bacteriuria in Pregnant Women at Kosti Teaching Hospital, Kosti-White Nile State (Sudan). Int.J.Curr.Microbiol.App.Sci. 7(06): 925-930. doi: https://doi.org/10.20546/ijcmas.2018.706.110 